\title{
The Brewer-Dobson circulation and total ozone from seasonal to decadal time scales
}

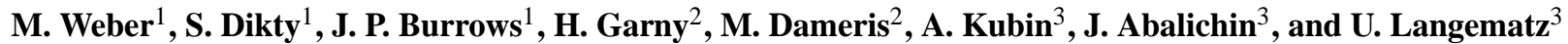 \\ ${ }^{1}$ Institut für Umweltphysik, Universität Bremen FB1, Bremen, Germany \\ ${ }^{2}$ Institut für Atmosphäre, Deutsches Zentrum für Luft- und Raumfahrt e.V., Oberpfaffenhofen, Germany \\ ${ }^{3}$ Institut für Meteorologie, Freie Universität Berlin, Berlin, Germany
}

Received: 25 March 2011 - Published in Atmos. Chem. Phys. Discuss.: 6 May 2011

Revised: 31 October 2011 - Accepted: 3 November 2011 - Published: 11 November 2011

\begin{abstract}
The effect of the winter Brewer-Dobson circulation (BDC) on the seasonal and decadal evolution of total ozone in both hemispheres is investigated using satellite total ozone data from the merged GOME/SCIAMACHY/GOME-2 (GSG) data set (19952010) and outputs from two chemistry-climate models (CCM), the FUB-EMAC and DLR-E39C-A models. Combining data from both hemispheres a linear relationship between the winter average extratropical $100 \mathrm{hPa}$ eddy heat flux and the ozone ratio with respect to fall ozone levels exists and is statistically significant for tropical as well as polar ozone. The high correlation at high latitudes persists well into the summer months until the onset of the next winter season. The anti-correlation of the cumulative eddy heat flux with tropical ozone ratios, however, breaks down in spring as the polar vortex erodes and changes to a weak positive correlation similar to that observed at high latitudes. The inter-annual variability and decadal evolution of ozone in each hemisphere in winter, spring, and summer are therefore driven by the cumulative effect of the previous winter's meridional circulation. This compact linear relationship is also found in both CCMs used in this study indicating that current models realistically describe the variability in stratospheric circulation and its effect on total ozone. Both models show a positive trend in the winter mean eddy heat flux (and winter BDC strength) in both hemispheres until year 2050, however the inter-annual variability (peak-to-peak) is two to three times larger than the mean change between 1960 and 2050. It is, nevertheless, possible to detect a shift in this compact linear relationship related to past and future changes in the strato-
\end{abstract}

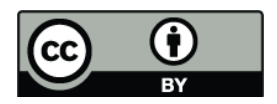

Correspondence to: $\mathrm{M}$. Weber (weber@uni-bremen.de) spheric halogen load. Using the SBUV/TOMS/OMI (MOD V8) merged data set (1980-2010), it can be shown that from the decade 1990-1999 to 2000-2010 this linear relationship remained unchanged (before and after the turnaround in the stratospheric halogen load), while a shift is evident between 1980-1989 (upward trend in stratospheric halogen) and the 1990 s, which is a clear sign that an onset of recovery is detectable despite the large variability in polar ozone. Because of the large variability from year to year in the BDC circulation substantial polar ozone depletion may still occur in coming decades in selected winters with weak BDC and very low polar stratospheric temperatures.

\section{Introduction}

For many years the main focus in studies of long-term ozone changes was the impact on chemical ozone loss from halogen containing anthropogenic ozone depleting substances (ODS) (WMO, 1999). Chemical mechanisms leading to chemical ozone losses, in particular heterogeneous ozone loss in the polar region (polar ozone loss), are now generally well understood (Solomon, 1999; WMO, 2003, 2007, 2011). More recently, studies of dynamical aspects in ozone changes, related to stratospheric circulation and meteorology, have become more important in particular with respect to the impact of climate change on ozone and vice versa. Ozone levels have started rising in accordance with the slowdown and reversal of stratospheric halogen increases, a consequence of the global phase-out of many ODS from the successful implementation of the Montreal Protocol and its amendments (WMO, 2007, 2011). The question arises how the climate and, in particular, associated changes in the stratospheric

Published by Copernicus Publications on behalf of the European Geosciences Union. 
circulation, will impact the speed of ozone recovery in coming decades.

The Brewer-Dobson circulation (BDC) generally describes the meridional transport of trace gases from the tropics to the poles (Brewer, 1949; Dobson, 1956). This circulation is now understood as a residual circulation since the general air flow remains zonal and planetary waves in the extratropics disturb this flow and cause a slow meridional drift (Haynes et al., 1991; Rosenlof and Holton, 1993; Newman et al., 2001; Plumb, 2002). The transport time of air in the stratosphere from the equator to the lowermost polar stratosphere is in the range of a few years (e.g. Waugh and Hall, 2002). The poleward transport of ozone is most effective in the winter hemisphere (e.g. Chipperfield and Jones, 1999). Several climate models and chemistry climate models (CCM) indicate that the strength of the winter BDC will increase with increasing greenhouse gas concentrations (GHG) and accelerate the expected ozone recovery (e.g. Rind et al., 1998; Butchart and Scaife, 2001; Schnadt et al., 2002; Rind et al., 2002; Sigmond et al., 2004; Eichelberger and Hartmann, 2005; Butchart et al., 2006; Jiang et al., 2007; Li et al., 2007; Eyring et al., 2007; Fomichev et al., 2007; Garcia and Randel, 2008; Butchart et al., 2010). Observational studies indicate that the stratospheric age-of-air (which should decrease if BDC is enhanced) did not change during recent decades (Engel et al., 2009), however, the available data for this study is quite sparse and large uncertainties for the trend estimates exists (Waugh, 2009). Very recently a new study, based on tracer-tracer correlations seems to indicate that at least in the shallow branch of the BDC (closer to the UTLS and subtropics) faster transport times are recently observed (Bönisch et al., 2011).

The planetary wave activity driving the BDC is usually described by the convergence of the Eliassen-Palm (EP) flux $\vec{F}$, i.e. $-\vec{\nabla} \cdot \vec{F}$. The convergence of the EP flux in the stratosphere is a measure for easterly momentum deposited to decelerate the westerly zonal flow in winter (Newman et al., 2001). Geostrophic balance then requires a small meridional flow component that initiates the meridional or residual circulation (Andrews et al., 1987). The vertical component of the EP flux vector, $F_{z}$, which is proportional to the eddy heat flux, $\overline{v^{\prime} T^{\prime}}$, is a measure of the vertical propagation of planetary waves from the troposphere. Both EP flux convergence and the eddy heat flux are frequently used to describe variations in the BDC driving.

Fusco and Salby (1999) and Salby and Callaghan (2004a) showed that inter-annual variation of the eddy heat flux correlates with year-to-year changes of extratropical column ozone and at the same time anti-correlates with ozone changes in the tropics, documenting the year-to-year variation in hemispheric ozone transport. Part of the long-term trend in extratropical total ozone in the Northern Hemisphere can be explained by changes in the winter BDC (Fusco and Salby, 1999; Randel et al., 2002; Dhomse et al., 2006). The magnitude of this contribution to the overall ozone trend strongly depends on the choice and details of dynamical proxy terms used in the trend regression (Steinbrecht et al., 1998; Hood and Soukharev, 2005; Reinsel et al., 2005; Dhomse et al., 2006; Wohltmann et al., 2007). Various proxies have been used in the trend models individually and in combination to describe dynamical ozone changes, like the potential vorticity or tropopause height, teleconnection patterns, e.g. Arctic Oscillation (AO), equivalent latitude proxy, and eddy heat flux. They are, however, not independent of each other as is discussed for the AO and eddy heat flux as an example in the following.

Figure 1 shows the evolution of middle latitude December to February (DJF) total ozone in the Northern Hemisphere starting in the 1960s. Also shown are the DJF Arctic oscillation in the middle panel (which is closely related to the North-Atlantic oscillation (NAO) defined by the surface pressure difference between Azores/Lisbon and Iceland) and the stratospheric halogen load (inverse scale for clarity) as represented by the equivalent effective stratospheric chlorine (EESC) (e.g. Newman et al., 2007) in the bottom panel.

The winter $\mathrm{AO}$ index represents changes in stratospheric dynamics in recent decades and they correlate with ozone changes (see smoothed lines in figure and Appenzeller et al. (2001)). The long-term changes in the AO index indicate possible long-term changes in the BDC (Fusco and Salby, 1999; Randel et al., 2002). Winters with extreme positive (negative) NAM values (northern annular mode, a new term for the Arctic oscillation, see Thompson et al. (2003)), correspond to years with small (high) winter eddy heat fluxes and strong (weak) polar night jets (Hartmann et al., 2000). An extreme negative AO index combined with an easterly QBO (quasi-biennial oscillation) phase lead to very high total ozone throughout the Northern Hemisphere (NH) in 2010 (Steinbrecht et al., 2011). The study by Kiesewetter et al. (2010a) showed that for winters in a high (low) annular mode state, negative (positive) upper stratospheric ozone anomalies in fall result in low (high) column ozone anomalies in polar spring. Low ozone in winter/spring is also expected from low winter planetary wave activity (weak BDC) and low polar temperatures during the winter season (Weber et al., 2003; Kawa et al., 2005; Sinnhuber et al., 2006).

Figure 1 seems to indicate that long-term ozone changes are correlated to both changes in stratospheric halogen and atmospheric dynamics. This close coupling between atmospheric dynamics and chemistry is also evident on interannual time scales as shown by the compact linear relationship between the cumulative hemispheric winter eddy heat flux and spring-to-fall polar total ozone ratio combining data from both hemispheres as reported by Weber et al. (2003). They also showed a corresponding anti-correlation with OClO columns from GOME observations, an indication of chlorine activation inside the polar vortex, that prove year-to-year variability in polar ozone loss are driven by coupled variations in atmospheric dynamics and polar chemistry (Weber et al., 2003; Tegtmeier et al., 2008). 


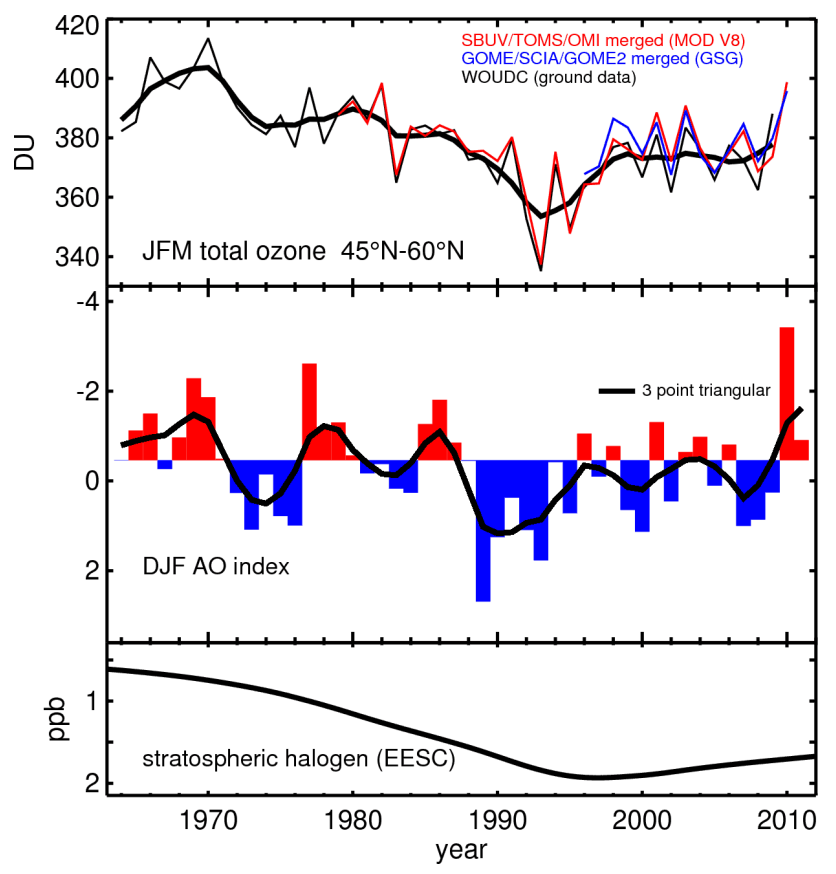

Fig. 1. Top: JFM total ozone area-weighted between $45^{\circ} \mathrm{N}$ and $60^{\circ} \mathrm{N}$ as measured from ground (Fioletov et al. (2002), WOUDC web site, http://www.woudc.org/data/summaries_e.html) and satellites (SBUV/TOMS/OMI merged data, MOD V8, in red, GOME/SCIAMACHY/GOME-2 merged data, GSG, in blue. The thick black line is the three point triangular smooth of the ground data. Middle panel: DJF Arctic oscillation index (blue values correspond to positive $\mathrm{AO}$ values) obtained from http://www.cpc.ncep. noaa.gov/products/precip/CWlink/daily_ao_index/ao.shtml. Thick black line is the three point triangular smooth of the AO index. Bottom panel: Equivalent effective stratospheric chlorine (EESC) drawn with a reversed y-axis. The EESC was obtained from http://acdb-ext.gsfc.nasa.gov/Data_services/automailer/index. $\mathrm{html}$ and calculated for a mean age of air of three years and bromine efficiency of $\alpha=60$ (Newman et al., 2006, 2007).

The goal of this paper is to elucidate further on the compact linear relationship between winter eddy heat flux and the ozone build-up as reported in our earlier study (Weber et al., 2003) by using in addition to observations results from two CCMs, the FUB-EMAC and DLR-E39C-A models. First, the two CCMs are compared to current observations and secondly the CCM data are used to look how such a dynamicschemistry coupling may change in the future in connection with climate change and ozone recovery. Section 2 briefly describes the total ozone data sets and the two CCMs (DLRE39C-A and EMAC-FUB) used in this study. Section 3 summarises results on the similarity of changes in the winter eddy heat flux, stratospheric temperature, and observed spring ozone in both hemispheres since the start of the satellite era at the end of the 1970s. The update on the compact linear relationship between the winter BDC and spring-tofall ozone ratio using more years of data from the GOME,
SCIAMACHY, and GOME-2 merged data set (GSG data) is presented in Sect. 4. The ozone anomaly as observed in spring persists throughout the summer months until begin of next fall and its connection to the previous winter's BDC is described and discussed in Sect. 5. Model results are presented in Sect. 6. The implications on future changes in the ozone - BDC interaction are also discussed in this section followed by conclusions from this study.

\section{Data}

\subsection{Observations}

The GOME/SCIAMACHY/GOME-2 total ozone merged data set, also called in short the GSG data set, has been compiled from observations made by GOME (Coldewey-Egbers et al., 2005; Weber et al., 2005), SCIAMACHY (Bracher et al., 2005), and GOME2 (Weber et al., 2007) instruments and starts in 1995. In the GSG data set the SCIAMACHY (2002-present) and GOME-2 (2007-present) data have been adjusted to the GOME data record (1995-present) by determining a mean scaling factor (GOME-2 and SCIAMACHY) and trend (SCIAMACHY only) in the monthly mean zonal mean ratios. Using the criterion of maximum global sampling, the GSG data set is then composed of GOME until June 2003, SCIAMACHY (2003-2006), and GOME-2 after 2006. More details can be found at and data are available from http://www.iup.uni-bremen.de/gome/wfdoas/merged/.

We also use the TOMS/SBUV merged total ozone data sets (http://acdb-ext.gsfc.nasa.gov/Data_services/merged/), which combines TOMS, SBUV(/2), and OMI total ozone data by removing biases and drifts between data sets in overlapping periods (Stolarski and Frith, 2006). These data encompass the time period from 1978 to present and the latest version is MOD V8.

\subsection{Chemistry-climate models}

The output from two CCMs is used to compare with observations and to discuss past and future changes in the relationship between the BDC and ozone. Major difference between the CCM EMAC-FUB and DLR-E39C-A is that the first is a high-top model with altitude levels up to the mesosphere $(0.01 \mathrm{hPa})$ and the latter a low top model $(10 \mathrm{hPa})$ with better vertical resolution in the UTLS (upper troposphere lower stratosphere). Both models have taken part in the SPARC CCMval activities (Eyring et al., 2005, 2007; SPARC-CCMVal, 2010). The DLR-E39C-A model is based on the general circulation model ECHAM4, coupled with the chemistry module CHEM and contains 39 layers extending to $10 \mathrm{hPa}$ (Stenke et al., 2009). The EMAC-FUB CCM consists of the ECHAM5-MESSy CCM (Jöckel et al., 2006) and includes the interactive chemistry module MECCA (Sander et al., 2005) as well as an improved short-wave radiation parameterisation (Nissen et al., 2007). It was run with a 
horizontal resolution of T42 $(2.8 \times 2.8)$ and 39 levels with the top at $0.01 \mathrm{hPa}$.

In this study model runs from 1960 until 2050 with prescribed GHG concentrations from the A1B scenario (IPCC, 2000) and surface mixing ratios of ozone depleting substances (ODS) based on the halogen A1 scenario from WMO (2007) are used. Both models include volcanic aerosols and assumed background stratospheric aerosols after year 2006 . Sea surface temperature and sea ice coverage are prescribed in the CCMs according to climate model projections. The solar activity cycles as well as the QBO are considered in both CCMs to include their impact on ozone-climate interaction. Details of the respectively chosen boundary conditions can be found in Eyring et al. (2008) and Morgenstern et al. (2010).

\section{Coupling of chemistry and dynamics of total ozone}

A key parameter for coupling atmospheric dynamics and chemistry is the stratospheric temperature (Newman et al., 2001; Salby and Callaghan, 2002). At lower temperatures the gas-phase catalytic cycles destroying ozone in the upper stratosphere slow down (Jonsson et al., 2004). This would mean that in a future changing climate with a stratosphere getting colder due to enhanced infrared GHG emission (e.g. Shindell et al., 1999), a super ozone recovery (a recovery to higher ozone levels than in the 1960s) could be expected (WMO, 2007). In the lower stratosphere, where the largest fraction of the total ozone column resides, temperature changes are primarily driven by atmospheric dynamics. Stratospheric cooling on one hand leads to additional polar ozone loss in winter. On the other hand, an enhancement in planetary wave activity results in instantaneous adiabatic compression in the polar region, in extreme cases in major stratospheric warmings, and corresponding adiabatic expansion in the tropics and cooling, driving temperatures in each case away from radiation equilibrium (Andrews et al., 1987; Kodera, 2006; Salby, 2008). This will result in less polar ozone depletion and enhanced ozone transport to high latitudes. The slow relaxation from the fast adiabatic response back to equilibrium temperatures then drives the residual or diabatic circulation with slow ascent in the tropics and descent in the polar region and determines the stratospheric age-of-air (Fels, 1982; Andrews et al., 1987).

The coupling of winter polar stratospheric temperature variations from year to year with corresponding changes in the winter mean eddy heat flux and $\mathrm{NH}$ polar ozone in spring is shown in Fig. 2. Atmospheric dynamics drives the inter-annual variability of polar stratospheric temperatures and ozone transport into the polar region (represented by the winter eddy heat flux) during winter. Another important aspect is that temperature controls polar ozone loss due to heterogeneous chemistry requiring polar stratospheric clouds to be formed (usually below $195 \mathrm{~K}$ ). The inter-annual

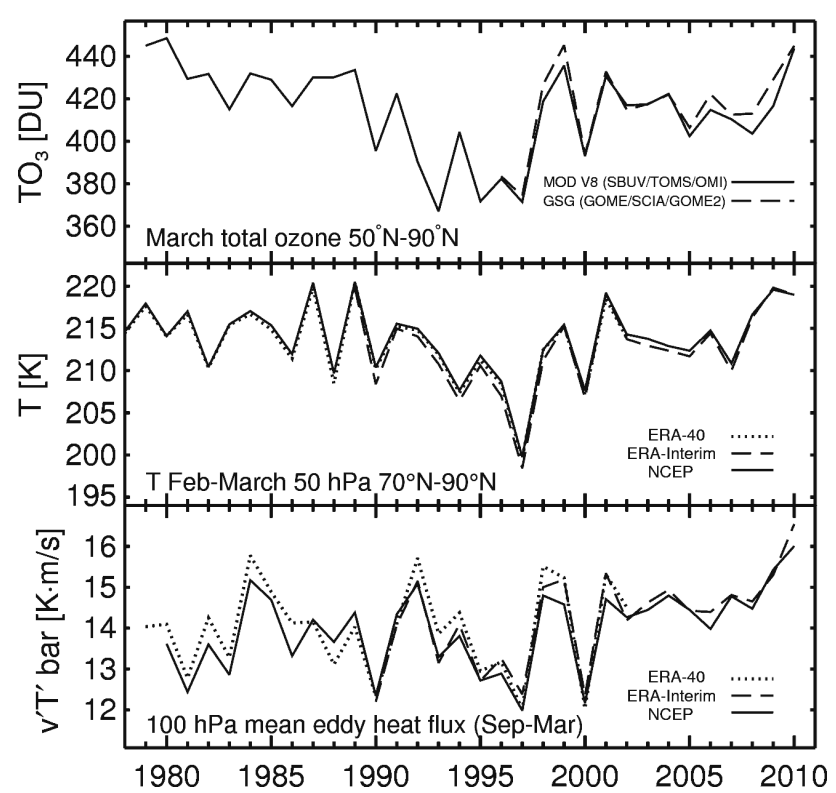

Fig. 2. Top: March total ozone area-weighted between $50^{\circ} \mathrm{N}$ and $90^{\circ} \mathrm{N}$ as measured from satellites (solid line: SBUV/TOMS/OMI merged data, dashed line: SCIAMACHY/GOME/GOME-2 merged data). Middle panel: $\mathrm{NH}$ area weighted polar cap temperature $\left(70^{\circ} \mathrm{N}-90^{\circ} \mathrm{N}\right)$ from three meteorological reanalyses (ECMWF ERA-40, ECMWF ERA-Interim, NCEP). Bottom panel: extratropical eddy heat flux at $100 \mathrm{hPa}$ averaged from September to March and area weight averaged between $45^{\circ} \mathrm{N}$ and $75^{\circ} \mathrm{N}$ derived from the same reanalyses.

variation of chlorine activation with variations in the winter eddy heat flux was shown from OClO data from GOME (Weber et al., 2003) that are indicative for chlorine activation and subsequent catalytic ozone losses inside the polar vortex (Solomon, 1999; Wagner et al., 2001; Richter et al., 2005). Figure 3 shows the corresponding figure for the SH. The correlation between temperature, winter planetary wave activity, and spring ozone in each hemisphere is particularly good for the late period after the middle 1990s and somewhat lower before.

The nearly linear decrease in SH polar spring ozone in the 1980s is not accompanied with corresponding changes in planetary wave activity and can be therefore more directly associated with upward trends in the halogen loading (see bottom of Fig. 1). The impact of the stratospheric aerosols from the Mt. Pinatubo major eruption in 1991 apparently also reduces this correlation. Following the Pinatubo event an increase in the winter mean eddy heat flux is evident in each hemisphere, but without corresponding increases in polar ozone. Sulfate aerosols contribute to ozone depletion via heterogeneous reactions that needs not to be limited to the polar vortex (Hofmann et al., 1994). However studies have shown that polar stratospheric temperatures where reduced in subsequent $\mathrm{NH}$ winters as well as tropical lowermost stratospheric 


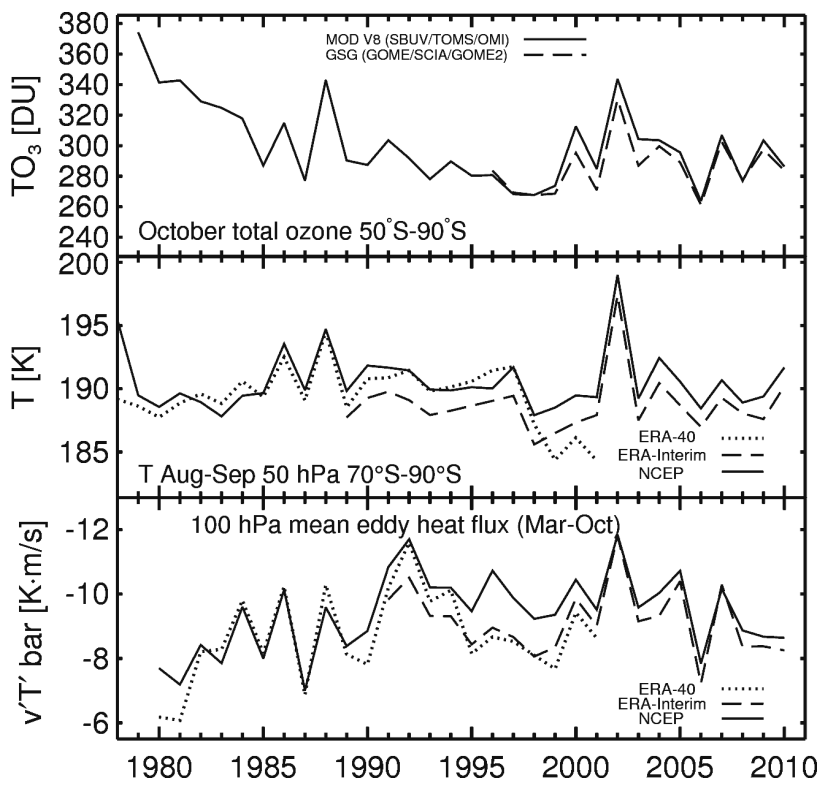

Fig. 3. Top: October total ozone area-weighted between $50^{\circ} \mathrm{S}$ and $90^{\circ} \mathrm{S}$ as measured from satellites (solid line: SBUV/TOMS/OMI merged data, dashed line: SCIAMACHY/GOME/GOME-2 merged data). Middle panel: SH area weighted polar cap temperature $\left(70^{\circ} \mathrm{S}-90^{\circ} \mathrm{S}\right)$ from different meteorological analyses. Bottom panel: extra-tropical eddy heat flux at $100 \mathrm{hPa}$ averaged from March to September and area weight averaged between $45^{\circ} \mathrm{S}$ and $75^{\circ} \mathrm{S}$ from different meteorological analysis.

temperature increased (Dhomse et al., 2006, Fig. 15) a typical signature of a reduced Brewer-Dobson circulation. Several other studies indicate that the stratospheric circulation was reduced and winter $\mathrm{AO}$ enhanced following the Pinatubo eruption (see for instance Stenchikov et al. (2004) and Fig. 1 in this paper).

\section{Linear correlation between BDC and ozone build-up}

The compact linear relationship between spring-to-fall polar ozone ratio and the winter mean eddy heat flux calculated for each hemisphere, respectively, is shown in Fig. 4. This figure combines data from the southern and Northern Hemisphere and is an update from Weber et al. (2003) and WMO (2007, Chapter 4) and includes more recent ozone data from SCIAMACHY and GOME-2 and covers the period 1995 to 2009. The SH winter eddy heat flux is negative but plotted here in absolute (positive) values. By combining data from both hemispheres the broad range of variation in the winter BDC strength from minimum values in the SH up to maximum values typical for $\mathrm{NH}$ winters and associated changes in the winter ozone build-up is visualised.
The spring ozone distribution is shown for selected winter seasons at the top of this figure demonstrating the gradual changes from ozone hole conditions typically in the $\mathrm{SH}$ to ozone rich distributions seen only in the NH. The BDC is known to be weaker in the $\mathrm{SH}$, where polar ozone loss outweighs the net transport into high latitudes, thus providing ozone ratios below one. One exception is the perturbed Antarctic ozone hole anomaly with the first major stratospheric warming observed in the SH (e.g. Weber et al., 2003; Sinnhuber et al., 2003; Richter et al., 2005; von Savigny et al., 2005) where the spring-to-fall polar ozone ratio is well above one. Polar ozone losses in the NH are more sporadic and ozone transport is generally more effective.

Normally the winter build up of ozone is strongest after late fall (November) as discussed in Fioletov and Shepherd (2003) and Salby and Callaghan (2004b), but here we use September in the NH and March in the SH, respectively, as starting point for the winter build-up. They are the months in the seasonal cycle where total ozone reaches its minimum (Weber et al., 2003; Fioletov and Shepherd, 2003).

Severe ozone losses in March were observed during the cold Arctic winters in the 1990s (1995/1996, 1996/1997, and 1999/2000) (Chapter 4 in WMO, 2007). Both the cold Arctic winters in the 1990s and the Antarctic ozone hole anomaly of 2002 represent in terms of the linear relationship shown in Fig. 4 an intermediate case between typical Antarctic and Arctic winters. The Antarctic winter 2006 was characterized by the largest ozone hole area (area covered by total ozone below $220 \mathrm{DU}$ ) observed in the GOME/SCIAMACHY era and was a result of an extremely weak winter BDC fostering very low polar stratospheric temperatures and, therefore, is located at the left lower end of the linear relationship shown in Fig. 4. Nevertheless, all special events, the Antarctic ozone hole in 2006, the ozone hole anomaly in 2002, and the cold Arctic winters are well covered by the linear relationship observed in Fig. 4.

\section{Seasonal persistence of total ozone variability}

In several studies it was shown that the inter-annual variations seen in polar total ozone anti-correlate with tropical ozone changes as a result of the overturning BDC (Fusco and Salby, 1999; Salby and Callaghan, 2004b). This is also evident from the change of the positive correlation of the winter accumulated eddy heat flux with polar ozone ratios into an anticorrelation in the tropics as is shown in Fig. 5. Here, the ozone ratios of February over September (NH) and August over March ( $\mathrm{SH}$ ) are displayed for several zonal bands ranging from the tropics to the polar region. This corresponds to a five month winter build up of ozone starting from September (NH) and March (SH), respectively. The correlation coefficients are very high and close to 0.9 and -0.9 in the polar and tropical region, respectively. The turnaround latitude where the correlation changes sign is within the 


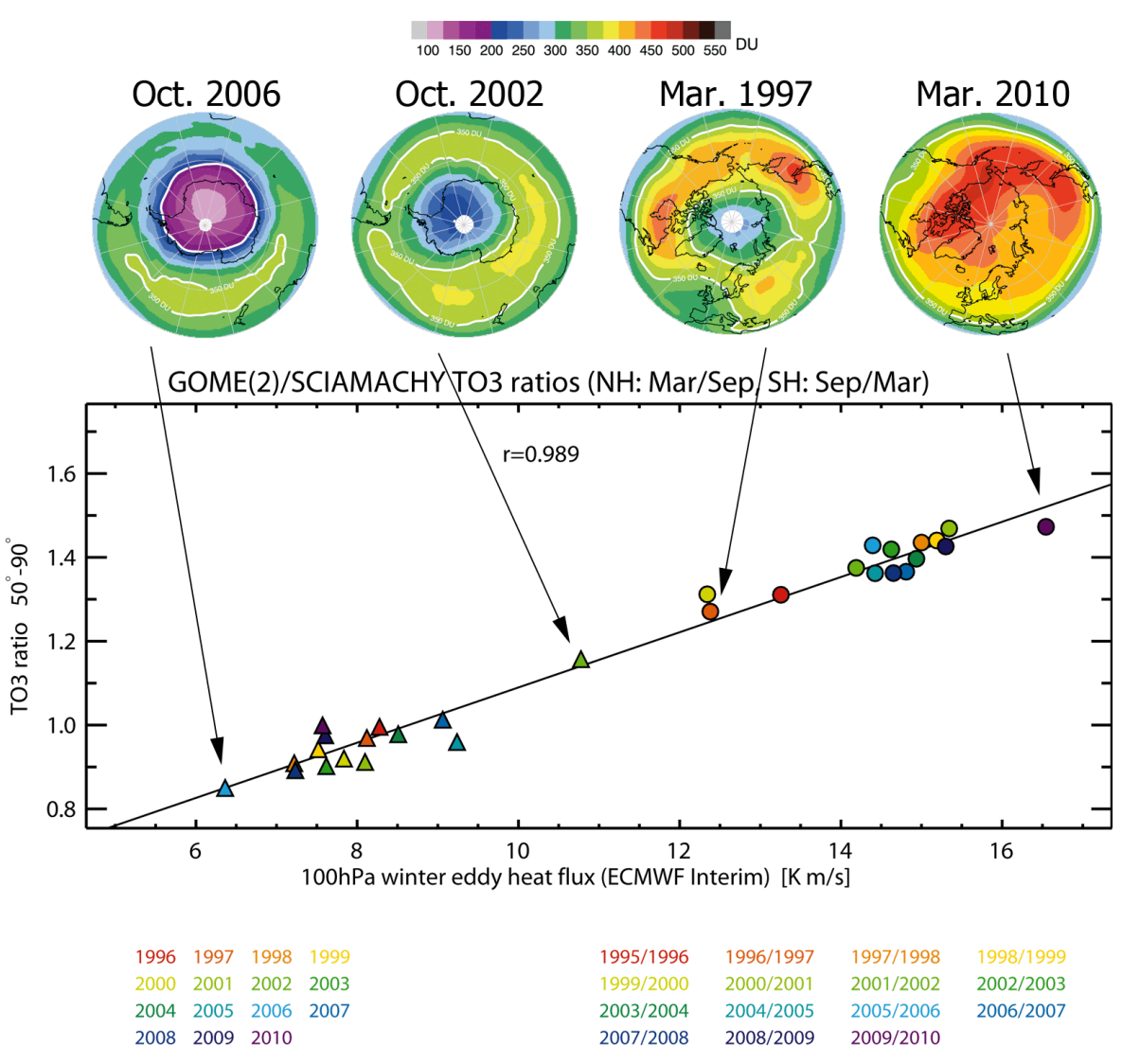

Fig. 4. Spring-to-fall ratio of observed polar cap total ozone $\left(>50^{\circ}\right)$ as a function of the absolute extratropical winter mean eddy heat flux (September to March and March to September in the respective hemispheres) derived from ECMWF ERA-Interim data separately in the respective hemisphere. Data from the Southern Hemisphere are shown as triangles (September over March ozone ratios) and from the Northern Hemisphere as solid circles (March over September ratios).

latitude band between $40^{\circ}$ and $50^{\circ}$, which can be interpreted as the zonal band where upwelling at low latitudes changes to downwelling in the extratropics as branches of the residual circulation.

Ozone anomalies at the end of winter persist throughout the summer months in the extratropics until fall, when photochemical equilibrium is reached and the residual circulation starts building up ozone for the next winter (Fioletov and Shepherd, 2003). The summertime changes in ozone are mainly governed by $\mathrm{NO}_{\mathrm{x}}$ chemistry in the absence of dynamic activity (Brühl et al., 1998; Brühl and Crutzen, 2000). As a consequence summertime trends are closely tied to winter trends (Fioletov and Shepherd, 2003, 2005).

In Fig. 6 the correlation coefficients of the linear relationship between ozone ratios and the average eddy heat flux for various zonal bands are plotted as a function of time from fall to fall next year. North of $45^{\circ}$ latitude the correlation is positive and negative at lower latitudes throughout the winter and early spring similar to that shown in Fig. 5 for a specific winter month. The positive correlation remains high for polar latitudes until next fall. In late spring and early summer the region of positive correlation extends from the polar re- gion to the subtropics. A possible explanation is the breakup of the polar vortex and the removal of the polar transport barrier that mixes or dilutes polar air into middle latitudes and to the subtropics and beyond (e.g. Knudsen and Grooß, 2000; Hadjinicolaou and Pyle, 2004; Ajtić et al., 2004; Fioletov and Shepherd, 2005). The anticorrelation observed at tropical latitudes goes to zero by early summer. The most likely explanation is the absence of dynamic activity in the summer hemisphere. Since variations in the tropics are lower than at high latitudes, the photochemical equilibrium is probably reached much faster than in the extratropics.

\section{Model results}

The analysis of the BDC impact on total ozone variability on time scales from seasonal to inter-annual described so far provides a valuable diagnostics for CCMs. The question arises how well do models compare with observations and what can models tell us about past and future changes. In Figs. 7 and 8 the seasonal correlation maps are shown for both CCMs, DLR-E39C-A and EMAC-FUB, respectively. 


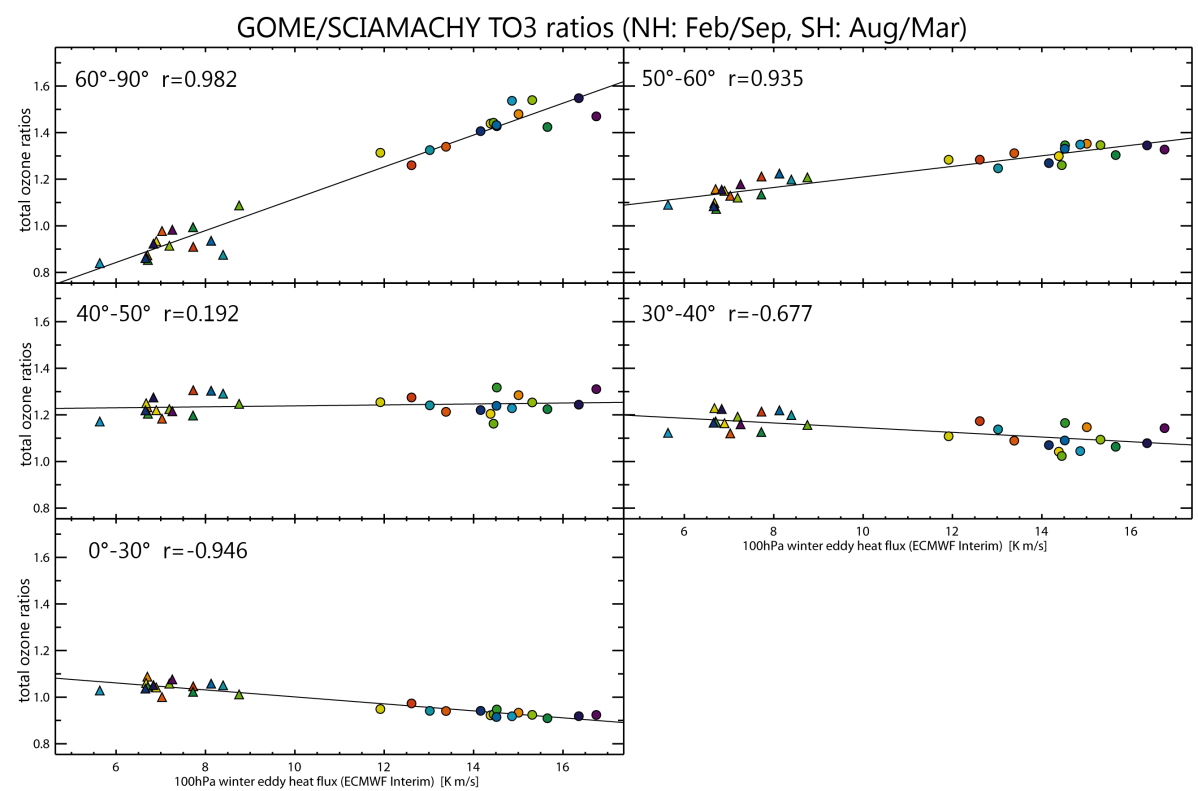

Fig. 5. Winter-to-fall ratio of observed total ozone for various zonal bands from the polar region to the tropics as a function of the mean absolute extratropical cumulative eddy heat flux between September and February in the NH and between March and August in the SH from ERA-Interim. Data from the Southern Hemisphere are shown as triangles (August over March ozone ratios) and from the Northern Hemisphere as solid circles (February over September ratios). Colors correspond to individual SH and NH winters as indicated in the bottom of Fig. 4.

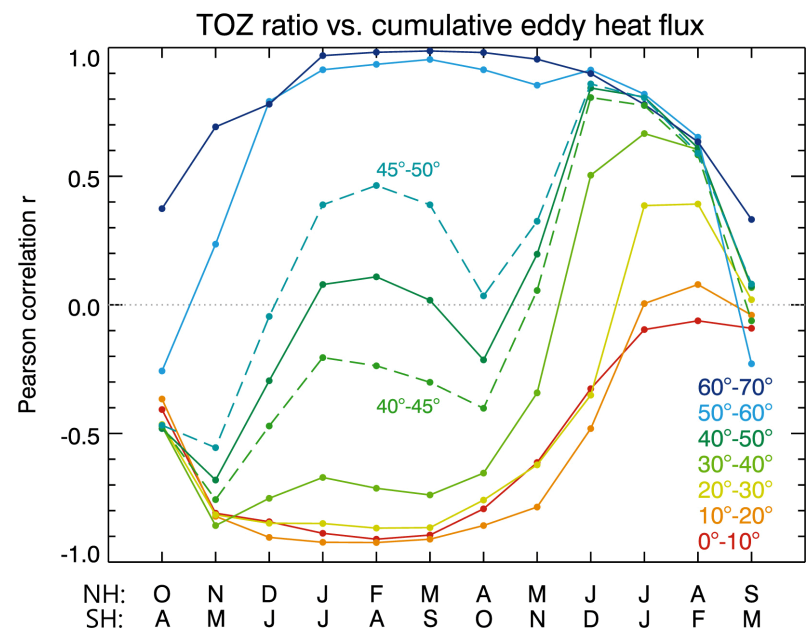

Fig. 6. Correlation between GOME/SCIAMACHY total ozone ratio (with respect to September in the $\mathrm{NH}$ and March in the $\mathrm{SH}$ ) and mean extratropical eddy heat flux averaged from starting month (September in the $\mathrm{NH}$ and March in the $\mathrm{SH}$ ) to the respective month indicated on the $\mathrm{x}$-axis for various zonal bands from the tropics to polar latitudes. Sample scatter plots for February (NH) and August (SH) data are shown in Fig. 5.

The model data are shown for years 1985 to 2010 to be comparable to observations shown in Fig. 6. The correlation maps with positive values in polar latitudes and negative in the tropics are qualitatively very similar to observa-

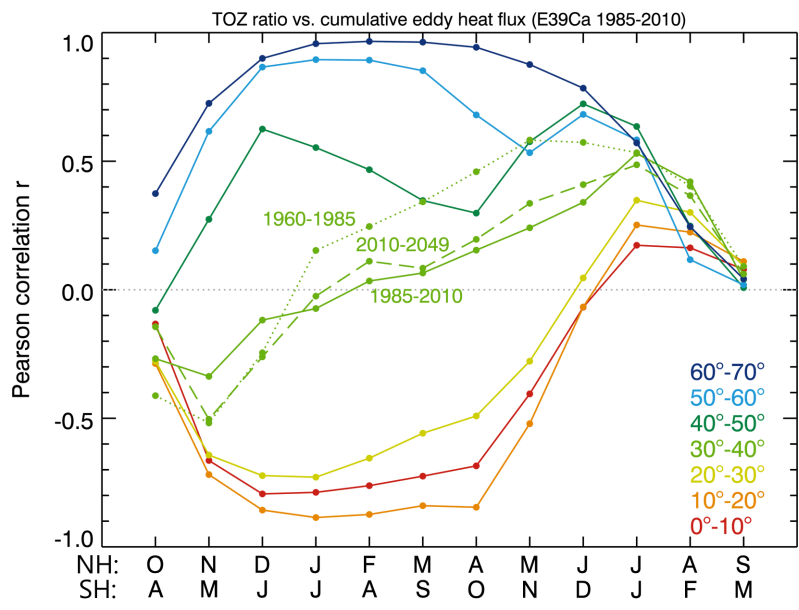

Fig. 7. Same as Fig. 6, but for CCM data from DLR-E39C-A model during the period 1985-2010. Dotted line shows the correlation of the $30^{\circ}-40^{\circ}$ zonal band for the time period $1960-1985$ (past) and the dashed line for 2010-2049 (future).

tions. The transition to summer conditions as characterized by the expansion of the positive correlation into middle latitudes also agrees with observations. The overall patterns in the winter/summer correlation appear realistic and are consistent with observations. 


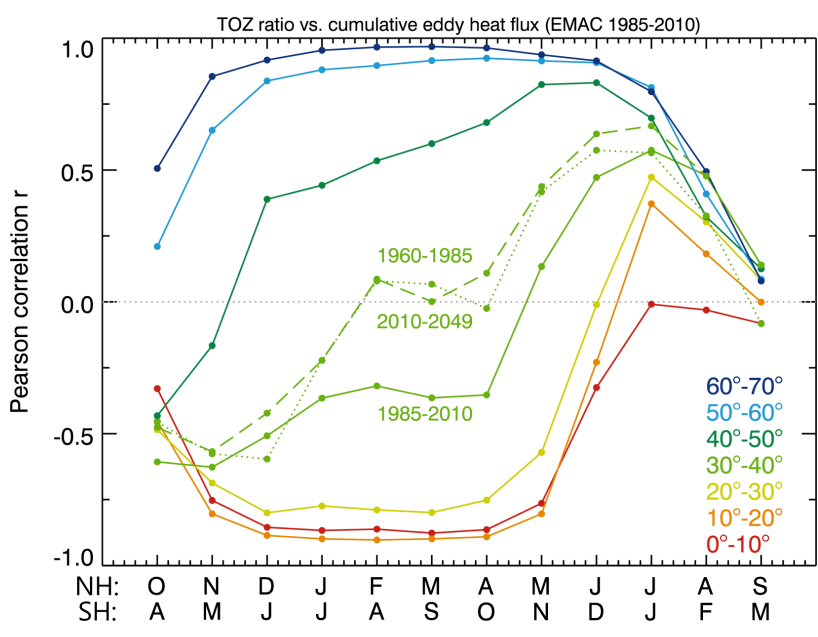

Fig. 8. Same as Fig. 7, but for CCM data from EMAC-FUB model.

Differences between models and observations are found in the transition zone from positive to negative correlations during winter. Observations indicate $45^{\circ}$ latitude (Fig. 6), while it lies equatorward of $40^{\circ}$ in both models. Figures 7 and 8 also show the changes with time in the transition zone. The dotted and dashed lines show the correlation of the $30^{\circ}-40^{\circ}$ zonal bands for the periods 1960-1985 (past) and 2010-2050 (future), respectively. In the DLR model it appears that the transition zone is nearly unaltered, only in the past it was slightly shifted to lower latitudes as evident from the higher and positive correlation. The FUB model shows a different behavior. In both past and future decades the transition is closer to about $35^{\circ}$ latitude and slightly shifted to higher latitudes in the period 1985-2010. The rough position of the modeled transition near $35^{\circ}$ latitude is close to the latitude separating tropical upwelling at lower latitudes from downwelling at higher latitudes shown in other model data (Austin and $\mathrm{Li}, 2006$ ).

During the summer months the correlation of polar ozone (and the anti-correlation of tropical ozone) with the average eddy heat flux from last winter starts to weaken about a month earlier in the DLR model compared to the FUB model and observations.

Figures 9 and 10 show the relationship of the spring-tofall polar total ozone ratio (September over March in the $\mathrm{SH}$ and March over September ratio in the NH) for the DLR and FUB models, respectively. Also shown are the GSG data set from Fig. 4. All model data from 1960-2050 are shown. Different colors are representing different time periods, grey for the past (1960-1985), black the present (1985-2010), and blue the future period (2010-2049). The corresponding regression line (dashed) for the three different periods is also shown. Since the ozone values in the DLR model show a consistent bias of about $50 \mathrm{DU}$ with respect to observations, an offset of $-50 \mathrm{DU}$ was applied to all DLR model data.
In general, the correlation in the relationship between polar ozone ratio and winter eddy heat flux is remarkably high and reproduces very well the observations. However, there are some differences with respect to observations. The spring-to-fall polar ozone ratios in the $\mathrm{SH}$ are in most cases above one, while observations are always below one except for the anomalous Antarctic ozone hole in 2002 indicating that ozone transport outweighs $\mathrm{SH}$ polar ozone loss in the models as opposed to observations. In both hemispheres the ozone ratios are in most cases higher than observations. A possible explanation for this could be that either modeled polar ozone losses are too low or that the polar vortex is more permeable due to numerical diffusion, meaning more mixing with middle latitude air occurs in the model (Austin et al., 2010).

One interesting aspect from the model studies is the evolution of this compact linear relationship on decadal time scales from the past into the future. The ozone ratios are smallest during the present period (1985-2010) compared to the past and future in both models. The long-term changes in the linear fits in Figs. 9 and 10 coincide with changes in the halogen loading (see Fig. 1 and Newman et al., 2007). During the period 1985-2010 the halogen loading reached a maximum and ozone losses in spring were maximum leading to lower spring-to-fall ozone ratios under identical meteorological/dynamical conditions of the polar winter stratosphere. Due to the phase-out of ozone depleting substances (WMO, 2007, 2011), the stratospheric halogen starts a slow decrease so that an increase in future ozone ratio and thus an upward shift in the linear fit curves back to the pre-ozone hole period 1960-1985 as shown in Figs. 9 and 10 is expected.

The upward shift of the regression line is smaller for the EMAC-FUB model than for DLR-E39C-A. This indicates that the ozone recovery is slower in the FUB model. However, both models are among the CCMs with faster ozone recovery (Austin et al., 2010; SPARC-CCMVal, 2010).

The variability in the modelled winter eddy heat fluxes (Figs. 9 and 10) is quite large in each hemisphere (spread across the $x$-direction of the plots) and is mostly in the range what is seen in the observations. The variability in the $\mathrm{NH}$ is somewhat smaller for the FUB model, when compared to the DLR model and observations. Both the FUB and DLR model have individual NH winters with extremely low winter eddy heat fluxes and spring-to-fall ozone ratios that are similar to Antarctic values. Such cases have not been seen in observations during the satellite era. On the other hand, none of the models was able to produce $\mathrm{SH}$ conditions similar to the Antarctic ozone hole anomaly observed in 2002.

No significant changes with time in the ranges of the winter eddy heat flux are evident in the models so that the largest changes with time in the compact linear relationship appear be due to changes in halogens and associated ozone chemistry. In Fig. 11 the time evolution of the CCM winter eddy heat flux in each hemisphere (averaged from September to March in the NH and March to September in the SH) is 


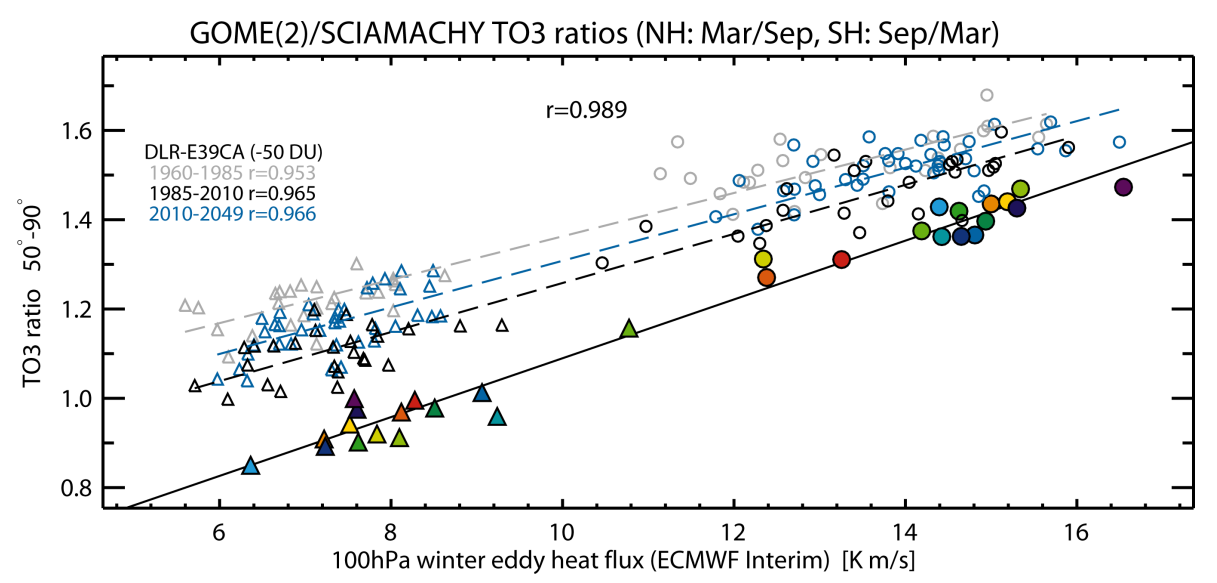

Fig. 9. Spring-to-fall ratio of polar cap total ozone $\left(>50^{\circ}\right)$ as a function of the absolute extratropical winter mean eddy heat flux from the DLR-E39C-A CCM. Data from the Southern Hemisphere are shown as triangles (September over March ozone ratios) and from the Northern Hemisphere as circles (March over September ratios). Different colors for the model data correspond to different time periods: past (1960-1985, grey), present (1985-2010, black), and future (2010-2050, blue). The colored points are the observational data as shown in Fig. 4

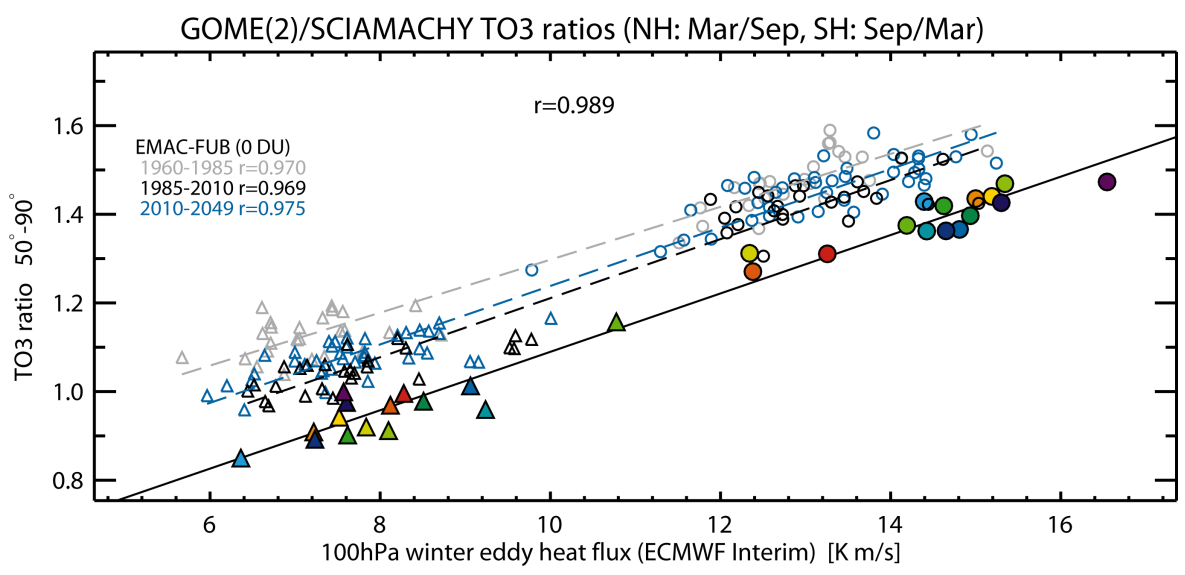

Fig. 10. Same as Fig. 9, but for CCM data from EMAC-FUB model.

displayed. Also shown are the decadal means of the same quantities (blue for $\mathrm{SH}$ and red for $\mathrm{NH}$ ) and the linear fit to the decadal means. A slow increase in the strength of the winter BDC and winter eddy heat flux from 1960 until 2050 is evident, which is $\sim+0.5 \mathrm{~K} \mathrm{~m} \mathrm{~s}^{-1}$ over the ninety year time span. The year-to-year variations are on the order of $1-2 \mathrm{~K} \mathrm{~m} \mathrm{~s}^{-1}$ which strongly masks the long-term trend. For a few decades the trends may even become reversed, e.g. 1990-2010 in the NH (DLR model) and 2000-2020 in the SH (FUB model), such that polar ozone losses can be intensified for one to two decades despite the slow decline in the stratospheric halogen loading.

In Fig. 11 the decadal means from NCEP reanalysis and ECMWF during the satellite period (1980-2010) are also shown. Over the three decades of the satellite era the increase in the observed winter eddy heat flux is a factor of two to three larger than the long-term change seen in the CCMs. From the variability evident in the model data it is most likely that the current observed trend may not be maintained over a longer time period into the future.

\section{Ozone recovery}

First signs of ozone recovery related to the turnaround in the halogen loading were observed in the upper stratosphere (Newchurch et al., 2003; Steinbrecht et al., 2009). However in the lower stratosphere, where the dominant contribution to the total ozone column comes from, the fingerprint of recovery is less clear due to the large influence from atmospheric dynamics (see Fig. 1). A large contribution to the strong increase in $\mathrm{NH}$ total ozone in the extratropics since 


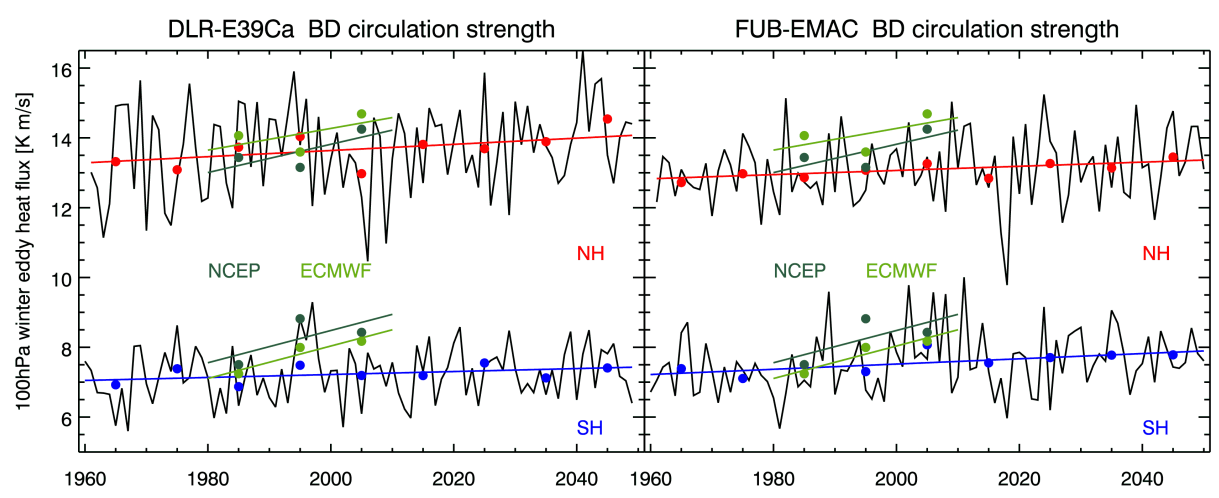

Fig. 11. Time series of annual winter averaged extratropical eddy heat flux (September to March and March to September in the respective hemisphere) derived from the DLR-E39C-A (left panel) and EMAC-FUB models (right panel) between year 1960 and 2050 separate for each hemisphere. The red and blue points as well as lines show the decadal means in the $\mathrm{NH}$ and $\mathrm{SH}$, respectively, and the corresponding regression line. Also shown in green are the decadal means from the NCEP and ECMWF reanalyses (1980s: ERA-40, 1990s and later: ERA-Interim) during the satellite era (1980-2010).

the middle 1990s is due to changes in the stratospheric circulation (Hadjinicolaou et al., 2005; Dhomse et al., 2006; Wohltmann et al., 2007; Harris et al., 2008; Kiesewetter et al., 2010b). Nevertheless, the upward shift in the linear regression in Figs. 9 and 10 confirms that ozone will steadily increase with sinking stratospheric halogen loading despite the large variability seen from year-to-year.

In Fig. 12 the total ozone - eddy heat flux relationship is shown for the MOD V8 merged data set going back to early 1980s. Ozone ratios for February, March, and April (August, September, and October in the $\mathrm{SH}$ ) are shown with different colors corresponding to different decades: red for 1980s, blue for 1990s, and green for the 1990s. The Pinatubo years $(1992,1993)$ are shown in black. This figure reveals a larger change from the 1980s to the 1990s (strong positive trend in halogens) and virtually no changes from the 1990s to 2000 s (during which the halogen load reached maximum and started slowly to decline, see EESC curves in the inlet). The changes from the 1980 to the later decades is particularly evident in the $\mathrm{SH}$ and is consistent with the ozone recovery in the SH observed by Salby et al. (2011). The correlation between eddy heat flux and total ozone appears somewhat less clear in the 1980s, particularly in the $\mathrm{SH}$, as compared to the later periods (see also Fig. 4). The most likely reason is that the quality of the meteorological reanalyses were less accurate when satellite data started to be integrated into the assimilation scheme in the 1980s (A. Simmons, personal communication, 2005).

Figure 12 also reveals that the halogen related ozone recovery is mostly detectable in the late winter and early spring, but not in the February ratios (August ratios in the $\mathrm{SH})$. The Pinatubo years clearly stand out and show lower ozone ratios than in other years with similar winter eddy heat flux values. An additional polar ozone loss of about $15 \%$ can be estimated from the shift in the linear curves during the
Pinatubo years. As discussed in the last paragraph of Section 3 , it is also possible that a high bias in the observed eddy heat flux during the Pinatubo years may explain part of this shift.

\section{Summary and conclusion}

In this paper we investigated the impact of the BDC on total ozone from seasonal to decadal time scales using satellite observations and two CCMs, the FUB-EMAC and DLRE39C-A models. From the long-term data record it is clear that long-term changes in total ozone in the extratropics, representative for lower stratospheric ozone, have contributions from changes in the upper atmospheric circulation (atmospheric dynamics) and in ozone chemistry (polar ozone losses and gas-phase losses) due to the halogen load. The chemical trends are tied to changes in meteorology and atmospheric dynamics as shown in Fig. 1. This is also evident on shorter time scales when looking at inter-annual variations in stratospheric temperatures (as a proxy for chemistry), extratropcial ozone, and BDC strength, here expressed by the winter eddy heat flux in each hemisphere (Figs. 2 and 3).

Combining data from both hemispheres a compact linear relationship exists between the winter eddy heat flux and the spring-to-fall ozone ratio as shown in Fig. 4. This figure is an update of Fig. 3 in Weber et al. (2003) with more years of data added and now showing a higher correlation coefficient $(r=0.992)$. This compact linear relationship marks as one extreme the Antarctic winters with a weak BDC, colder polar lower stratospheric temperatures, the ozone hole, and the other extreme the Arctic winters with higher stratospheric temperatures, larger ozone transport, and reduced polar ozone losses. The anomalous SH ozone hole in 2002 (Sinnhuber et al., 2003; Richter et al., 2005; von Savigny et al., 2005) with unusually enhanced 


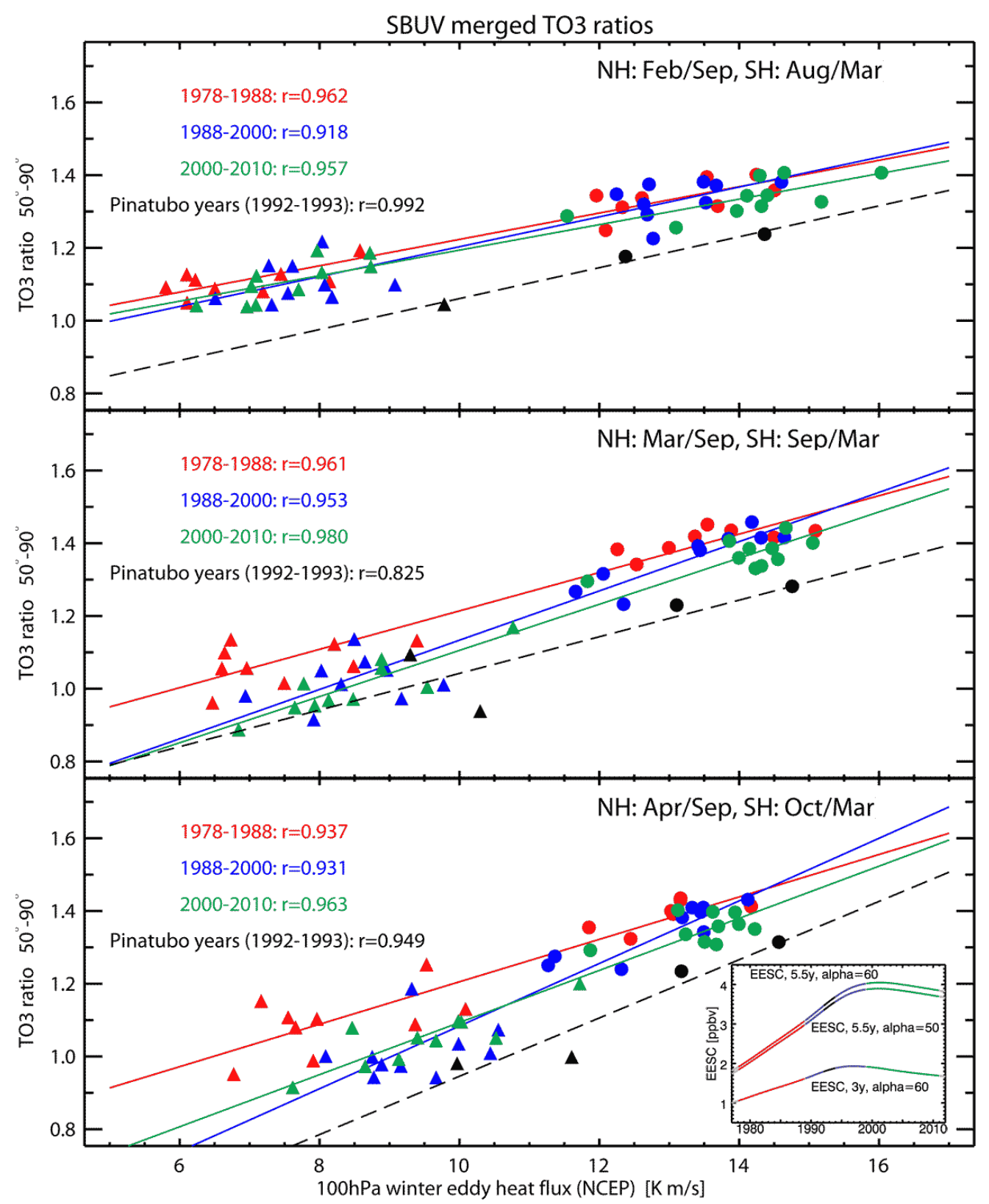

Fig. 12. Same as Figure 4 but using the SBUV/TOMS/OMI merged ozone data (MOD V8) and NCEP reanalysis data. Different colors represent different decades, red for the 1980s, blue for the 1990s, and green for the 2000s. Black data correspond to the Pinatubo years (1992-1993). From top to bottom: Total ozone ratios for February, March, and April over September, respectively, in the NH and August, September, and October over March, respectively, in the SH. As an insert in the bottom panel different EESC curves are shown for different mean ages and bromine efficiencies $(\alpha)$. Stratospheric age of air of 5.5 years is representative for polar latitudes, while 3 years are more appropriate for middle latitudes (Newman et al., 2006, 2007).

ozone transport into polar latitudes and the cold Arctic winters in the 1990s with reduced ozone transport and larger polar ozone losses fit into this remarkable relationship. The tropical ozone ratios in contrast are anti-correlated to the winter-eddy heat flux as shown in Fig. 5.

The correlation between the eddy heat flux averaged from fall to the respective month and the corresponding ozone ra- tios remain high throughout spring until the end of the summer (Fig. 6). The positive correlation as seen in the extratropics during late spring and summer also extends into the tropical region after the polar vortex breaks up. This is consistent with results from Fioletov and Shepherd $(2003,2005)$ who investigated the seasonal autocorrelation of total ozone and its impact on long-term trends. The transition zone between 
negative correlation (tropics) and positive correlation (extratropics) during winter is at about $45^{\circ}$ latitude. This is consistent with the fact that the sign of stratospheric temperature departure from radiative equilibrium reverses at the same latitude, meaning it is negative equatorward (tropical cooling and upwelling) and positive poleward of this latitude as noted by Ueyama and Wallace (2010).

The seasonal correlation pattern as shown for observational data is also very well reproduced by two chemistryclimate models, the DLR-E39C-A and the EMAC-FUB (Figs. 7 and 8), that were run from year 1960 to 2050. One notable difference with respect to observations is that the transition zone between positive correlations in the extratropics and negative correlations in the tropics is somewhat shifted towards lower latitudes near $35^{\circ}$. A compact linear relationship between polar spring-to-fall ozone ratio and the modelled winter eddy heat flux is seen in both models, clearly indicating that the overall BDC pattern on total ozone is well reproduced by the models (Figs. 9 and 10). However, the spring-to-fall ozone ratios are generally higher than the observed ones. The linear regression of this relationship shifts due to the reversal of the stratospheric halogen trends meaning that under near identical meteorological conditions and dynamic state of the atmosphere the recovery of total ozone in the future is evident. As shown in this study (Fig. 12) and by others (Mäder et al., 2010; Salby et al., 2011), a beginning ozone recovery from the turnaround in stratospheric halogen loading is detectable despite the large inter-annual variability in observed total ozone.

Both models show a positive trend in the winter eddy heat flux indicating that in a changing climate the BDC may intensify in coming decades, a feature which is observed by many other CCMs (see Sect. 1). Nevertheless the year-toyear variability in the winter BDC strength is a factor of three to four higher than the decadal mean change from 1960 to 2050. For one or two decades as e.g. 1990-2010 in the NH (DLR model) and 2000-2020 in the SH (FUB model) a negative trend in the winter eddy heat flux may occur that could lead to more severe polar ozone loss despite the slow decline in the stratospheric halogen load.

Acknowledgements. This work was supported by the DFG Research Unit FOR 1095 "Stratospheric Change and its Role for Climate Prediction" (SHARP) and the SHARP-OCF Project, Geschäftszeichen BU 688/22-1, and SHARP-BDC, Geschäftszeichen DA 233/3-1 and LA 1025/13-1. Part of this work was also funded by the State of Bremen. ECMWF reanalysis data has been provided by the ECMWF Special Project DECDIO. FUB would like to thank Patrick Jöckel (DLR) for helpful advice and support with the EMAC-FUB CCM.

Edited by: F. Khosrawi

\section{References}

Ajtić, J., Connor, B. J., Lawrence, B. N., Bodeker, G. E., Hoppel, K. W., Rosenfield, J. E., and Heuff, D. N.: Dilution of the Antarctic ozone hole into southern midlatitudes, 1998-2000, J. Geophys. Res., 109, D17107, doi:10.1029/2003JD004500, 2004.

Andrews, D. G., Holton, J. R., and Leovy, C. B.: Middle Atmosphere Dynamics, Academic Press, San Diego, CA, USA, 1987.

Appenzeller, C., Weiss, A. K., and Staehelin, J.: North Atlantic Oscillation modulates total ozone winter trends, Geophys. Res. Lett., 27, 1131-1134, 2001.

Austin, J. and Li, F.: On the relationship between the strength of the Brewer-Dobson circulation and the age of stratospheric air, Geophys. Res. Lett., 330, L178070, doi:10.1029/2006GL026867, 2006.

Austin, J., Struthers, H., Scinocca, J., Plummer, D. A., Akiyoshi, H., Baumgaertner, A. J. G., Bekki, S., Bodeker, G. E., Braesicke, P., Brühl, C., Butchart, N., Chipperfield, M. P., Cugnet, D., Dameris, M., Dhomse, S., Frith, S., Garny, H., Gettelman, A., Hardiman, S. C., Jöckel, P., Kinnison, D., Kubin, A., Lamarque, J. F., Langematz, U., Mancini, E., Marchand, M., Michou, M., Morgenstern, O., Nakamura, T., Nielsen, J. E., Pitari, G., Pyle, J., Rozanov, E., Shepherd, T. G., Shibata, K., Smale, D., Teyssèdre, H., and Yamashita, Y.: Chemistry-climate model simulations of spring Antarctic ozone, J. Geophys. Res., 115, D00M11, doi:10.1029/2009JD013577, 2010.

Bönisch, H., Engel, A., Birner, T., Hoor, P., Tarasick, D. W., and Ray, E. A.: On the structural changes in the Brewer-Dobson circulation after 2000, Atmos. Chem. Phys., 11, 3937-3948, doi:10.5194/acp-11-3937-2011, 2011.

Bracher, A., Lamsal, L. N., Weber, M., Bramstedt, K., ColdeweyEgbers, M., and Burrows, J. P.: Global satellite validation of SCIAMACHY $\mathrm{O}_{3}$ columns with GOME WFDOAS, Atmos. Chem. Phys., 5, 2357-2368, doi:10.5194/acp-5-2357-2005, 2005.

Brewer, A. W.: Evidence for a world circulation provided by measurements of helium and water vapor distribution in the stratosphere, Q. J. Roy. Meteorol. Soc., 75, 351-363, 1949.

Brühl, C. and Crutzen, P. J.: $\mathrm{NO}_{\mathrm{x}}$-catalyzed ozone destruction and $\mathrm{NO}_{\mathrm{x}}$ activation at midlatitudes to high latitudes as the main cause of the spring to fall ozone decline in the Northern Hemoisphere, J. Geophys. Res., 105, 12163-12168, 2000.

Brühl, C., Crutzen, P. J., and Grooss, J.: High-latitude, summertime $\mathrm{NO}_{\mathrm{x}}$ activation and seasonal ozone decline in the lower stratosphere: Model calculations based upon HALOE on UARS, J. Geophys. Res., 103, 3587-3597, 1998.

Butchart, N. and Scaife, A. A.: Removal of chlorofluorocarbons by increased mass exchange between the stratosphere and troposphere in a changing climate, Nature, 410, 799-802, 2001.

Butchart, N., Scaife, A. A., Bourqui, M., de Grandpré, J., Hare, S. H. E., Kettleborough, J., Langematz, U., Manzini, E., Sassi, F., Shibata, K., Shindell, D., and Sigmond, M.: Simulations of anthropogenic change in the strength of the Brewer-Dobson circulation, Clim. Dynam., 27, 727-741, 2006.

Butchart, N., Cionni, I., Eyring, V., Shepherd, T. G., Waugh, D. W., Akiyoshi, H., Austin, J., Brühl, C., Chipperfield, M. P., Cordero, E., Dameris, M., Deckert, R., Dhomse, S., Frith, S. M., Garcia, R. R., Gettelman, A., Giorgetta, M. A., Kinnison, D. E., Li, F., Mancini, E., McLandress, C., Pawson, S., Pitari, G., Plummer, D. A., Rozanov, E., Sassi, F., Scinocca, J. F., Shibata, K., Steil, 
B., and Tian, W.: Chemistry-climate model simulations of 21st century stratospheric climate and circulation changes, J. Clim., 23, 5349-5374, doi:10.1175/2010JCLI3404.1, 2010.

Chipperfield, M. P. and Jones, R. L.: Relative influences of atmospheric chemistry and transport on Arctic ozone trends, Nature, 400, 551-554, 1999.

Coldewey-Egbers, M., Weber, M., Lamsal, L. N., de Beek, R., Buchwitz, M., and Burrows, J. P.: Total ozone retrieval from GOME UV spectral data using the weighting function DOAS approach, Atmos. Chem. Phys., 5, 5015-5025, doi:10.5194/acp5-5015-2005, 2005.

Dhomse, S., Weber, M., Burrows, J., Wohltmann, I., and Rex, M.: On the possible causes of recent increases in NH total ozone from a statistical analysis of satellite data from 1979 to 2003 , Atmos. Chem. Phys., 6, 1165-1180, doi:10.5194/acp-6-1165-2006, 2006.

Dobson, G. M.: Origin and distribution of the polyatomic molecules in the atmosphere, Proc. Roy. Soc. Ldn., A236, 187-193, 1956.

Eichelberger, S. J. and Hartmann, D.: Changes in the strength of the Brewer-Dobson circulation in a simple AGCM, Geophys. Res. Lett., 32, L15807, doi:10.1029/2005GL022924, 2005.

Engel, A., Möbius, T., Bönisch, H., Schmidt, U., Heinz, R., Levin, I., Atlas, E., Aoki, S., Nakazawa, T., Sugawara, S., Moore, F., Hurst, D., Elkins, J., Schauffler, S., Andrews, A., and Boering, K.: Age of stratospheric air unchanged within uncertainties over the past 30 years, Nature Geosci., 2, 28-31, doi:10.1038/ngeo388, 2009.

Eyring, V., Harris, N., Rex, M., Sheperd, T. G., Fahey, D. W., Amanatidis, G. T., Austin, J., Chipperfield, M. P., Dameris, M., De, P. M., Forster, F., Gettelman, A., Graf, H. F., Nagashima, T., Newman, P. A., Pawson, S., Prather, M. J., Pyle, J. A., Salawitch, R. J., Santer, B. D., and Waugh, D. W.: A strategy for processoriented validation of coupled chemistry-climate models, B. Am. Meteorol. Soc., 86, 1117, doi:10.1175/BAMS-86-8-1117, 2005.

Eyring, V., Waugh, D. W., Bodeker, G. E., Cordero, E., Akiyoshi, H., Austin, J., Beagley, S. R., Boville, B. A., Braesicke, P., Brühl, C., Butchart, N., Chipperfield, M. P., Dameris, M., Deckert, R., Deushi, M., Frith, S. M., Garcia, R. R., Gettelman, A., Giorgetta, M. A., Kinnison, D. E., Mancini, E., Manzini, E., Marsh, D. R., Matthes, S., Nagashima, T., Newman, P. A., Nielsen, J. E., Pawson, S., Pitari, G., Plummer, D. A., Rozanov, E., Schraner, M., Scinocca, J. F., Semeniuk, K., Shepherd, T. G., Shibata, K., Steil, B., Stolarski, R. S., Tian, W., and Yoshiki, M.: Multi-model projections of stratospheric ozone in the 21st century, J. Geophys. Res., 112, D16303, doi:10.1029/2006JD008332, 2007.

Eyring, V., Gettelman, A., Harris, N. R. P., Pawson, S., Shepherd, T. G., Waugh, D. W., Akiyoshi, H., Butchart, N., Chipperfield, M., Dameris, M., Fahey, D. W., Forster, P. M. F., Newman, P. A., Rex, M., Salawitch, R. J., and Santer, B. D.: Overview of the new CCMVal reference and sensitivity simulations in support of upcoming ozone and climate assessments and planned SPARC CCMVal, SPARC Newsletter, 30, 20-26, 2008.

Fels, S. B.: A parameterization of scale-dependent radiative damping rates in the middle atmosphere, J. Atmos. Sci., 39, 1141$1152,1982$.

Fioletov, V. E. and Shepherd, T. G.: Seasonal persistence of midlatitude total ozone anomalies, Geophys. Res. Lett., 30, 1417, doi:10.1029/2002GL016739, 2003.

Fioletov, V. E. and Shepherd, T. G.: Summertime total ozone vari- ations over middle and polar latitudes, Geophys. Res. Lett., 32, L04807, doi:10.1029/2004GL022080, 2005.

Fioletov, V. E., Bodeker, G. E., Miller, A. J., McPeters, R. D., and Stolarski, R.: Global and zonal total ozone variations estimated from ground-based and satellite measurements: 1964-2000, J. Geophys. Res., 107, 4647, doi:10.1029/2001JD001350, 2002.

Fomichev, V. I., Jonsson, A. I., de Grandpré, J., Beagley, S. R., McLandress, C., Semeniuk, K., and Shepherd, T. G.: Response of the middle atmosphere to $\mathrm{CO}_{2}$ doubling: Results from the Canadian Middle Atmosphere Model, J. Clim., 20, 1121-1144, doi:10.1175/JCLI4030.1, 2007.

Fusco, A. C. and Salby, M. L.: Interannual variations of total ozone and their relationship to variations of planetary wave activity, J. Clim., 12, 1619-1629, 1999.

Garcia, R. R. and Randel, W. J.: Acceleration of the Brewer-Dobson circulation due to increases in greenhouse gases, J. Atmos. Sci., 65, 2731-2739, doi:10.1175/2008JAS2712.1, 2008.

Hadjinicolaou, P. and Pyle, J. A.: The Impact of Arctic Ozone Depletion on Northern Middle Latitudes: Interannual Variability and Dynamical Control, J. Atmos. Chem., 47, 25-43, doi:10.1023/B:JOCH.0000012242.06578.6c, 2004.

Hadjinicolaou, P., Pyle, J. A., and Harris, N. R. P.: The recent turnaround in stratospheric S4810 ozone over northern middle latitudes: A dynamical modeling perspective, Geophys. Res. Lett., 32, L12821, doi:10.1029/2005GL022476, 2005.

Harris, N. R. P., Kyrö, E., Staehelin, J., Brunner, D., Andersen, S.B., Godin-Beekmann, S., Dhomse, S., Hadjinicolaou, P., Hansen, G., Isaksen, I., Jrrar, A., Karpetchko, A., Kivi, R., Knudsen, B., Krizan, P., Lastovicka, J., Maeder, J., Orsolini, Y., Pyle, J. A., Rex, M., Vanicek, K., Weber, M., Wohltmann, I., Zanis, P., and Zerefos, C.: Ozone trends at northern mid- and high latitudes, Ann. Geophys., 26, 1207-1220, 2008.

Hartmann, D. L., M.Wallace, J., Limpasuvan, V., Thompson, D., and Holton, J. R.: Can ozone depletion and global warming interact to produce rapid climate change?, Proc. Natl. Acad. Sci., 97, 1412-1417, 2000.

Haynes, P. H., Marks, C. J., McIntyre, M. E., Shepherd, T. G., and Shine, K. P.: On the "downward control" of extratropical diabatic circulations by eddy-induced mean zonal forces, J. Atmos. Sci., 48, 651-678, 1991.

Hofmann, D., Oltmans, S., Komhyr, W., Harris, J., Lathrop, J., Deshler, T., Johnson, B., Torres, A., and Matthews, W.: Ozone loss in the lower stratosphere over the United States in 19921993: Evidence for heterogeneous chemistry on the Pinatubo aerosol, Geophys. Res. Lett., 21, 65-68, 1994.

Hood, L. L. and Soukharev, B. E.: Interannual variations of total ozone at northern midlatitudes correlated with EP flux and potential vorticity, J. Atmos. Sci., 62, 3724-3740, 2005.

IPCC: Special Report on Emissions Scenarios: a Special Report of Working Group III of the Intergovernmental Panel on Climate Change, Cambridge University Press, Cambridge, UK, 2000.

Jiang, X., Eichelberger, S. J., Hartmann, D., Shia, R., and Yung, Y. L.: Influence of doubled $\mathrm{CO}_{2}$ on ozone via changes in the Brewer-Dobson circulation, J. Atmos. Sci., 64, 2751-2755, 2007.

Jöckel, P., Tost, H., Pozzer, A., Brühl, C., Buchholz, J., Ganzeveld, L., Hoor, P., Kerkweg, A., Lawrence, M., Sander, R., Steil, B., Stiller, G., Tanarhte, M., Taraborrelli, D., van Aardenne, J., and Lelieveld, J.: The atmospheric chemistry general circulation 
model ECHAM5/MESSy1: Consistent simulation of ozone from the surface to the mesosphere, Atmos. Chem. Phys., 6, 50675104, doi:10.5194/acp-6-5067-2006, 2006.

Jonsson, A., de Grandpre, J., Fomichev, V., McConnell, J., and Beagley, S.: Doubled CO2-induced cooling in the middle atmosphere: Photochemical analysis of the ozone radiative feedback, J. Geophys. Res., 109, D24103, doi:10.1029/2004JD005093, 2004.

Kawa, S. R., Newman, P. A., Stolarski, R. S., and Bevilacqua, R. M.: Fall vortex ozone as a predictor of springtime total ozone at high northern latitudes, Atmos. Chem. Phys., 5, 1655-1663, doi:10.5194/acp-5-1655-2005, 2005.

Kiesewetter, G., Sinnhuber, B.-M., Vountas, M., Weber, M., and Burrows, J. P.: A long-term stratospheric ozone dataset from assimilation of satellite observations: Highlatitude ozone anomalies, J. Geophys. Res., 115, D10307, doi:10.1029/2009JD013362, 2010a.

Kiesewetter, G., Sinnhuber, B.-M., Weber, M., and Burrows, J. P.: Attribution of stratospheric ozone trends to chemistry and transport: a modelling study, Atmos. Chem. Phys., 10, 12 073-12 089, doi:10.5194/acp-10-12073-2010, www. atmos-chem-phys.net/10/12073/2010/, 2010b.

Knudsen, B. M. and Grooß, J.-U.: Northern midlatitude stratospheric ozone dilution in spring modeled with simulated mixing, J. Geophys. Res., 105, 6885-6890, 2000.

Kodera, K.: Influence of stratospheric sudden warming on the equatorial troposphere, Geophys. Res. Lett., 33, L06804, doi:10.1029/2005GL024510, 2006.

Li, F., Austin, J., and Wilson, J.: The strength of the Brewer-Dobson circulation in a changing climate: Coupled chemistry-climate model simulations, J. Clim., 21, 40-57, 2007.

Mäder, J. A., Staehelin, J., Peter, T., Brunner, D., Rieder, H. E., and Stahel, W. A.: Evidence for the effectiveness of the Montreal Protocol to protect the ozone layer, Atmos. Chem. Phys., 10, 19005-19029, doi:10.5194/acpd-10-19005-2010, 2010.

Morgenstern, O., Giorgetta, M. A., Shibata, K., Eyring, V., Waugh, D. W., Shepherd, T. G., Akiyoshi, H., Austin, J., Baumgaertner, A. J. G., Bekki, S., Braesicke, P., Brühl, C., Chipperfield, M. P., Cugnet, D., Dameris, M., Dhomse, S., Frith, S. M., Garny, H., Gettelman, A., Hardiman, S. C., Hegglin, M. I., Jöckel, P., Kinnison, D. E., Lamarque, J., Mancini, E., Manzini, E., Marchand, M., Michou, M., Nakamura, T., Nielsen, J. E., Olivié, D., Pitari, G., Plummer, D. A., Rozanov, E., Scinocca, J. F., Smale, D., Teyssédre, H., Toohey, M., Tian, W., and Yamashita, Y.: Review of the formulation of present-generation stratospheric chemistryclimate models and associated external forcings, J. Geophys. Res., 115, D00M02, doi:10.1029/2009JD013728, 2010.

Newchurch, M. J., Yang, E. S., Cunnold, D. M., Reinsel, G. C., Zawodny, J. M., and Russel III, J. M.: Evidence for slowdown in stratospheric ozone loss: First stage of ozone recovery, J. Geophys. Res., 108, 4507, doi:10.1029/2003JD003471, 2003.

Newman, P. A., Nash, E., and Rosenfield, J.: What controls the temperature of the Arctic stratosphere during the spring?, J. Geophys. Res., 106, 19999-20010, 2001.

Newman, P. A., Nash, E. R., Kawa, S. R., Montzka, S. A., and Schauffler, S. M.: When will the Antarctic ozone hole recover?, Geophys. Res. Lett., 33, L12814, doi:10.1029/2005GL025232, 2006.

Newman, P. A., Daniel, J. S., Waugh, D. W., and Nash, E. R.: A new formulation of equivalent effective stratospheric chlorine (EESC), Atmos. Chem. Phys., 7, 4537-4552, doi:10.5194/acp7-4537-2007, 2007.

Nissen, K., Matthes, K., Langematz, U., and Mayer, B.: Towards a better representation of the solar cycle in general circulation models, Atmos. Chem. Phys., 7, 5391-5400, doi:10.5194/acp-75391-2007, 2007.

Plumb, R. A.: Stratospheric transport, J. Meteor. Soc. Jpn., 80, 793809, 2002.

Randel, W. J., Wu, F., and Stolarski, R. S.: Changes in column ozone correlated with the stratospheric EP flux, J. Meteorol. Soc. Jpn., 80, 849-862, 2002.

Reinsel, G., Miller, A. J., Weatherhead, E. C., L. E. Flynn, R. M. N., Tiao, G. C., and Wuebbles, D. J.: Trend analysis of total ozone data for turnaround and dynamical contributions, J. Geophys. Res., 110, D16306, doi:10.1029/2004JD004662, 2005.

Richter, A., Wittrock, F., Weber, M., Beirle, S., Kühl, S., Platt, U., Wagner, T., Wilms-Grabe, W., and Burrows, J. P.: GOME observations of stratospheric trace gas distributions during the splitting vortex event in the Antarctic winter 2002. Part I: Measurements, J. Atmos. Sci., 62, 778-785, 2005.

Rind, D., Shindell, D., Lonergan, P., and Balachandran, N. K.: Climate change and the middle atmosphere. Part III: The double $\mathrm{CO}_{2}$ climate revisited, J. Clim., 11, 876-894, 1998.

Rind, D., Lerner, J., Perlwitz, J., McLinden, C., and Prather, M.: Sensitivity of tracer transports and stratospheric ozone to sea surface temperature patterns in the doubled $\mathrm{CO}_{2}$ climate, J. Geophys. Res., 107, doi:10.1029/2002JD002483, 2002.

Rosenlof, K. H. and Holton, J. R.: Estimates of stratospheric residual circulation using the downward principle, J. Geophys. Res., 98, 10465-10479, 1993.

Salby, M.: Involvement of the Brewer-Dobson circulation in changes of stratospheric temperature and ozone, Dyn. Atmos. Oceans, 44, 143-164, doi:10.1016/j.dynatmoce.2006.11.002, 2008.

Salby, M. and Callaghan, P.: Systematic changes of northern hemispheric ozone and their relationship to random interannual changes, J. Clim., 17, 4512-4521, 2004a.

Salby, M. and Callaghan, P.: Interannual changes of the stratospheric circulation: influence on the tropics and southern hemisphere, J. Clim., 17, 952-964, 2004b.

Salby, M., Titova, E., and Deschamps, L.: Rebound of Antarctic ozone, Geophys. Res. Lett., 38, L09702, doi:10.1029/2011GL047266, 2011.

Salby, M. L. and Callaghan, P. F.: Interannual changes of the stratospheric circulation: Relationship to ozone and tropospheric structure, J. Climate, 15, 3673-3685, 2002.

Sander, R., Kerkweg, A., Jöckel, P., and Lelieveld, J.: Technical Note: The new comprehensive atmospheric chemistry module MECCA, Atmos. Chem. Phys., 5, 445-450, doi:10.5194/acp-5445-2005, 2005.

Schnadt, C., Dameris, M., Ponater, M., Hein, R., Grewe, V., and Steil, B.: Interaction of atmospheric chemistry and climate and its impact on stratospheric ozone, Clim. Dynam., 18, 501-517, 2002.

Shindell, D. T., Rind, D., Balachandran, N., Lean, J., and Lonergan, P.: Solar cycle variability, ozone, and climate, Science, 284, 305308, 1999.

Sigmond, M. P., Siegmund, C., Manzini, E., and Kelder, H.: A 
simulation of the separate climate effects of middle atmospheric and tropospheric $\mathrm{CO}_{2}$ doubling, J. Clim., 17, 2352-2367, 2004.

Sinnhuber, B.-M., Weber, M., Amankwah, A., and Burrows, J. P.: Total ozone during the unusual Antarctic winter of 2002, Geophys. Res. Lett., 30, 1580, doi:10.1029/2002GL016798, 2003.

Sinnhuber, B.-M., von der Gathen, P., Sinnhuber, M., Rex, M., König-Langlo, G., and Oltmans, S. J.: Large decadal scale changes of polar ozone suggest solar influence, Atmos. Chem. Phys., 6, 1835-1841, doi:10.5194/acp-6-1835-2006, 2006.

Solomon, S.: Stratospheric ozone depletion: A review of concepts and history, Geophys. Rev., 101, 275-316, 1999.

SPARC-CCMVal: SPARC Report on the Evaluation of ChemistryClimate Models, SPARC Report No. 5, WCRP-132, WMO/TDNo. 1526, edited by: Eyring, V., Shepherd, T. G., and Waugh, D. W., www.atmosp.physics.utoronto.ca/SPARC, last access: May 2011, 2010.

Steinbrecht, W., Claude, H., and Köhler, U.: Correlations between tropopause height and total ozone: Implications for long-term changes, J. Geophys. Res., 103, 19183-19192, 1998.

Steinbrecht, W., Claude, H., Schönenborn, F., McDermid, I. S., Leblanc, T., Godin-Beekmann, S., Keckhut, P., Hauchecorne, A., Gijsel, J. A. E. V., Swart, D. P. J., Bodeker, G. E., Parrish, A., Boyd, I. S., Kämpfer, N., Hocke, K., Stolarski, R. S., Frith, S. M., Thomason, L. W., Remsberg, E. E., Savigny, C. V., Rozanov, A., and Burrows, J. P.: Ozone and temperature trends in the upper stratosphere at five stations of the Network for the Detection of Atmospheric Composition Change, Int. J. Remote Sens., 30, 3875-3886, 2009.

Steinbrecht, W., Köhler, U., Claude, H., Weber, M., Burrows, J. P., and van der A, R. J.: Very high ozone columns at northern mid-latitudes in 2010, Geophys. Res. Lett., 38, L06803, doi:10.1029/2010GL046634, 2011.

Stenchikov, A., Hamilton, K., Robock, A., Ramaswamy, V., and Schwarzkopf, M. D.: Arctic oscillation response to the 1991 Pinatubo eruption in the SKYHI general circulation model with a realistic quasi-biennial oscillation, J. Geophys. Res., 109, D03112, doi:10.1029/2003JD003699, 2004.

Stenke, A., Dameris, M., Grewe, V., and Garny, H.: Implications of Lagrangian transport for simulations with a coupled chemistry-climate model, Atmos. Chem. Phys., 9, 5489-5504, doi:10.5194/acp-9-5489-2009, 2009.

Stolarski, R. S. and Frith, S. M.: Search for evidence of trend slowdown in the long-term TOMS/SBUV total ozone data record: the importance of instrument drift uncertainty, Atmos. Chem. Phys., 6, 4057-4065, doi:10.5194/acp-6-4057-2006, 2006.

Tegtmeier, S., Rex, M., Wohltmann, I., and Krüger, K.: Relative importance of dynamical and chemical contributions to Arctic wintertime ozone, Geophys. Res. Lett., 35, L17801, doi:10.1029/2008GL034250, 2008.

Thompson, D. W. J., Lee, S., and Baldwin, M. P.: Atmospheric processes governing the Northern Hemisphere Annular Mode/North Atlantic Oscillation, in: The North Atlantic Oscillation: Climatic Significance and Environmental Impact, edited by Hurrell, J. W., Kushnir, Y., Ottersen, G., and Visbeck, M., vol. 134 of Geophysical Monograph, American Geophysical Union, Washington, DC, 81-112, 2003.

Ueyama, R. and Wallace, J. M.: To what extent does high-latitude wave forcing drive tropical upwelling in the Brewer-Dobson circulation?, J. Atmos. Sci., 67, 1232-1246,
doi:10.1175/2009JAS3216.1, 2010.

von Savigny, C., Rozanov, A., Bovensmann, H., Eichmann, K.-U., Noel, S., Rozanov, V. V., Sinnhuber, B.-M., Weber, M., Burrows, J. P., and Kaiser, J.: The ozone hole break-up in September 2002 as seen by SCIAMACHY on ENVISAT, J. Atmos. Sci., 62, 721734, 2005.

Wagner, T., Leue, C., Pfeilsticker, K., and Platt, U.: Monitoring of the stratospheric chlorine activation by GOME OClO measurements in the austral and boreal winters 1995 through 1999, J. Geophys. Res., 106, 4971-4996, 2001.

Waugh, D.: Atmospheric dynamics: The age of stratospheric air, Nature Geosci., 2, 14-16, doi:10.1038/ngeo397, 2009.

Waugh, D. W. and Hall, T. M.: Age of stratospheric air: Theory, observations, and models, Geophys. Rev., 40, 1010, doi:10.1029/2000RG000101, 2002.

Weber, M., Dhomse, S., Wittrock, F., Richter, A., Sinnhuber, B.M., and Burrows, J. P.: Dynamical control of NH and SH winter/spring total ozone from GOME observations in 1995-2002, Geophys. Res. Lett., 30, 1853, doi:10.1029/2002GL016799, 2003.

Weber, M., Lamsal, L. N., Coldewey-Egbers, M., Bramstedt, K., and Burrows, J. P.: Pole-to-pole validation of GOME WFDOAS total ozone with groundbased data, Atmos. Chem. Phys., 5, 1341-1355, doi:10.5194/acp-5-1341-2005, 2005.

Weber, M., Lamsal, L. N., and Burrows, J. P.: Improved SCIAMACHY WFDOAS total ozone retrieval: Steps towards homogenising long-term total ozone datasets from GOME, SCIAMACHY, and GOME2, in: Proc. Envisat Symp. Montreux, Switzerland, 2007, ESA SP-636, European Space Agency, http://envisat.esa.int/envisatsymposium/ proceedings/posters/3P4/463281we.pdf, last access: May 2011, 2007.

WMO: Scientific Assessment of Ozone Depletion: 1998, Global Ozone Research and Monitoring Project Report 44, World Meteorological Organization, Geneva, 1999.

WMO: Scientific Assessment of Ozone Depletion: 2002, Global Ozone Research and Monitoring Project Report 47, World Meteorological Organization, Geneva, www.wmo.int/pages/prog/ arep/gaw/ozone_2002/ozone_2002.html, last access: May 2011, 2003.

WMO: Scientific Assessment of Ozone Depletion: 2006, Global Ozone Research and Monitoring Project Report 50, World Meteorological Organization, Geneva, www.wmo.int/pages/prog/ arep/gaw/ozone_2006/ozone_asst_report.html, last access: May 2011, 2007.

WMO: Scientific Assessment of Ozone Depletion: 2010, Global Ozone Research and Monitoring Project Report 52, World Meteorological Organization, Geneva, www.unep.ch/ ozone/Assessment_Panels/SAP/Scientific_Assessment_2010/ 00-SAP-2010-Assement-report.pdf, last access: May 2011, 2011.

Wohltmann, I., Lehmann, R., Rex, M., Brunner, D., and Mäder, J. A.: A process-oriented regression model for column ozone, J. Geophys. Res., 112, D12304, doi:10.1029/2006JD007573, 2007. 